\title{
Penanaman Nilai-Nilai Pendidikan Agama Islam Pada Masa Pandemi Covid-19 Di Madrasah Ibtidaiyah
}

\author{
Faiqotul Laili \\ MI Al Ikhlas Bagorejo Srono \\ 0805faiqohlalala@gmail.com \\ Paga Tri Barata \\ Chongraksat Wittaya School Pattani Thailand \\ fagacrw@chongraksat.ac.th
}

DOI: $10.35719 /$ educare.v2i1.48

\begin{abstract}
The inculcation of Islamic religious values is an effort to shape the character of students to achieve a degree as a human being who is in accordance with norms, culture and religion. This research describes the process of internalization and the method of cultivating Islamic religious values in an unusual situation, namely in the era of the Covid-19 pandemic. In this study, researchers used a qualitative approach, a type of case study with interview and observation data collection techniques. The results of this study indicate that the implementation of student learning in a pandemic situation is carried out in two ways, namely (1) online and (2) offline. The values instilled in students include (a) worship, (b) faith and (c) morals. Meanwhile, the methods used by teachers in the process of inculcating Islamic religious values during the pandemic were practice methods, guidance methods, and memorization methods.
\end{abstract}

Keywords: Education, Islamic Religious Values, Covid-19

\begin{abstract}
Abstrak
Penanaman nilai-nilai agama Islam merupakan sebuah upaya dalam membentuk karakter peserta didik untuk mencapai derajat sebagai manusia yang sesuai norma, budaya serta agama. penelitian ini mendeskripsikan proses internalisasi hingga metode penanaman nilai-nilai agama Islam di situasi yang tidak biasa yakni di era pandemi covid-19. Dalam penelitian ini, peneliti menggunakan pendekatan kualitatif, jenis studi kasus dengan teknik pengumpulan data wawancara dan observasi. Hasil dari penelitian ini
\end{abstract}


menunjukkan bahwa pelaksanaan pembelajaran peserta didik dalam situasi pandemi dilakukan dengan dua cara yakni (1) daring dan (2) luring. Nilainilai yang ditanamkan kepada peserta didik meliputi (a) ibadah, (b) keimanan dan (c) akhlak. Sedangkan metode-metode yang digunakan guru dalam proses penanaman nilai-nilai agama Islam selama pandemi adalah metode praktik, metode bimbingan, dan metode hafalan.

\section{Kata Kunci: Pendidikan, Nilai Agama Islam, Covid-19}

\section{PENDAHULUAN}

Pada akhir tahun 2019, dunia dilanda virus yang mematikan dan kemudian status darurat virus ini dinyatakan sebagai pandemi oleh WHO (World Health Organization). Virus ini pertama ditemukan di Negara China yakni di kota Wuhan. Nama virus ini adalah Covid-19 (Corona virus disease 2019), seperti yang dinyatakan oleh WHO di website resminya, dan di laporkan pada 20 Januari 2020 bahwa "Covid-19 is the disease caused by a new coronavirus called SARS-CoV-2. WHO first learned of this new virus on 31 December 2019, following a report of a cluster of cases of 'viral pneumonia' in Wuhan, People's Republic of China." "Virus ini menyebar cepat ke seluruh dunia. Pada tanggal 30 Januari 2020, WHO menetapkan Covid-19 sebagai Public Health Emergency of International Concern (PHEIC)/ Kedaruratan Kesehatan Masyarakat yang Meresahkan Dunia (KKMMD). Dilansir dari dokumen resmi pada 27 Maret 2020 yang diterbitkan oleh Direktorat Jenderal Pencegahan dan Pengendalian Penyakit dan dimuat resmi di website Kementerian Kesehatan Republik Indonesia bahwa pada tanggal 2 Maret 2020 Indonesia, melaporkan bahwa 2 kasus terkonfirmasi Covid-19, dan pada tanggal 11 Maret 2020 WHO sudah menetapkan Covid-19 sebagai pandemi. ${ }^{2}$

"WHO, "Coronavirus Desiase (Covid-19)" dalam https://www.who.int/emergencies/diseases/novel-coronavirus-2019/question-and-answershub/q-a-detail/coronavirus-disease-covid-19, diakses pada 08 September 2020.

2 Kementerian Kesehatan. "Dokumen Resmi Direktorat Jenderal Pencegahan dan Pengendalian Penyakit, Akses Pada 28 Desember 2020”. 
Ditetapkannya Covid-19 oleh WHO sebagai pandemi, tentunya memiliki pengaruh besar terhadap aktivitas dunia termasuk Indonesia. Pengaruh yang besar dirasakan dampaknya dalam aktivitas ekonomi dan sosial, seperti yang dilansir oleh CNN Indonesia dalam berita digitalnya, bahwa dampak pandemi Covid-19 ini menyebabkan kinerja pasar modal menurun, dunia usaha rugi, pengangguran naik dan kemiskinan semakin bertambah. ${ }^{3}$ Bahkan dampak pandemi ini juga memberi dampak besar terhadap aktivitas pendidikan di Indonesia, yakni diliburkannya sekolah formal tatap muka dan diganti dengan pembelajaran online. Rizqon Halal Syah Aji dalam jurnal penelitiannya, bahwa dampak Covid-19 ini juga mengganggu aktivitas belajar peserta didik di sekolah, kerugian peserta didik dalam proses penilaian dan memiliki dampak terhadap lulusan sekolah. $^{4}$

Dari beberapa dampak yang disebutkan di atas, tampak jelas bahwa virus ini benar-benar membawa perubahan besar terhadap situasi di sekolah dan bagaimanapun juga menuntut pemerintah untuk berpikir keras dan cepat tentang ini, karena pendidikan merupakan faktor yang sangat penting dan tidak dapat dipisahkan didalam kehidupan manusia. Sebagaimana tertuang dalam Undang Undang RI Nomor 20 Tahun 2003 tentang Sistem Pendidikan Nasional BAB VIII pasal 34 ayat 1 mengenai wajib belajar, bahwa "Setiap warga Negara yang berusia 6 (enam) tahun dapat mengikuti program wajib belajar" dan ayat 3 "Wajib belajar merupakan tanggung jawab Negara yang diselenggarakan oleh lembaga pendidikan pemerintah, pemerintah daerah dan masyarakat". 5 Disisi lain, pendidikan berhak didapatkan setiap warga Negara demi berlangsungnya keseimbangan sosial,

3 CNN Indonesia, "Dampak Resesi Corona Mengalir ke Berbagai Sektor" dalam https://cnnindonesia.com/ekonomi/20200908105412-532-543899/dampak-resesi-coronamengalir-ke-berbagai-sektor/, diakses pada 09 Septemper- 2020.

${ }^{4}$ Rizqan Halal Syah Aji, "Dampak Covid-19 pada Pendidikan di Indonesia: Sekolah, Keterampilan, dan Proses Pembelajaran”, Salam: Jurnal Sosial \& Budaya Syar'I FSH UIN Syarif Hidayatullah Jakarta, Vol. 7, No. 5 (2020), 396.

5 Depdiknas, "Undang Undang Sistem Pendidikan Nasional No. 20 Tahun 2003" (Jakarta: Sinar Grafika, 2014), 23. 
hal ini memiliki kesamaan dengan yang diungkapkan oleh United Nations Educational, Scientific, and Cultural Organization (UNESCO) bahwa "UNESCO believes that seducation is a human right for all throught out life and that access must be matched by quality". 6

Selain pemerintah, para guru juga dituntut untuk bekerja ekstra dalam situasi pandemi ini dibandingkan pada kondisi-kondisi sebelumnya. Hal ini dilakukan demi mempertahankan keberlangsungan proses pembelajaran meskipun harus dilakukan dengan cara berbeda yaitu dengan cara daring (dalam jaringan), ${ }^{7}$ terhubung melalui jaringan komputer, internet dan sebagainya. Hal ini dilakukan sesuai surat edaran dari kemendikbud pada 17 Maret 2020, yang dimuat dalam website resminya dan disebutkan pada poin ke 4 (empat) huruf a dan b, bahwa "Khusus daerah yang sudah terdampak Covid-19 berlaku ketentuan sebagai berikut: (1) Memberlakukan pembelajaran secara daring dari rumah bagi peserta didik dan mahapeserta didik; (2) Pegawai, guru, dan dosen melakukan aktivitas bekerja, mengajar atau memberi kuliah dari rumah (Bekerja Dari Rumah/ BDR) melalui video conference, digital documents, dan sarana daring lainnya". ${ }^{8}$

Pembelajaran sistem daring dimungkinkan bisa berjalan dengan mulus untuk pembelajaran bertipe transfer of knowledge (seperti menghafal dan mengerjakan perhitungan), namun disisi lain dimungkinkan juga mengalami kesulitan untuk tipe pembelajaran transfer of value (seperti penanaman nilai-nilai karakter ataupun nilai-nilai agama). Oleh karena itu, maka dalam hal ini peneliti mencoba mengkaji secara mendalam bagaimana proses penanaman nilai-nilai agama yang dilakukan oleh MI Al Ikhlas Bagorejo Srono Kabupaten Banyuwangi di era pandemi Covid-19 tentunya dengan

6 UNESCO, Education Transforms Lives, https://en.unesco.org/themes/education, diakses pada 09 September 2020.

${ }^{7}$ Mendikbud, Kamus Besar Bahasa Indonesia, https://kbbi.kemdikbud.go.id/entri/daring, diakses pada 15 Oktober 2020.

${ }^{8}$ Mendikbud, Pembelajaran Secara Daring dan Bekerja dari Rumah untuk Mencegah Penyebaran Covid-19, https://www.kemdikbud.go.id/main/blog/2020/03/se-mendikbudpembelajaran-secara-daring-dan-bekerja-dari-rumah-untuk-mencegah-penyebaran-covid19, diakses pada 1 Oktober 2020. 
memperhatikan surat edaran dari Kemendikbud yang telah disampaikan di atas. Diharapkan dari hasil penelitian ini dapat memberikan gambaran dalam menangani hal serupa bagi pendidik (guru) atau akademisi serta dapat berkontribusi dalam dunia pendidikan khususnya dalam penanaman nilainilai agama dalam situasi darurat seperti era pandemi Covid-19 saat ini yang tengah dihadapi.

\section{METODE PENELITIAN}

Secara metodologis, dalam penelitian ini peneliti menggunakan pendekatan kualitatif. Pendekatan ini digunakan karena peneliti akan memaparkan hasil penelitiannya dalam bentuk kata-kata dan analisis data dalam bentuk kesimpulan deskriptif. Peneliti menggunakan pendekatan ini berlandaskan pada pendapat Sugiyono, bahwa penelitian kualitatif bertujuan untuk mengonstruksi atau menginterpretasikan kedalam bentuk makna dan kemudian akan menjelaskan masalah yang akan dikaji di lapangan. ${ }^{9}$ Sedangkan jenis penelitian yang akan digunakan oleh peneliti adalah jenis penelitian studi kasus. Pertimbangan menggunakan jenis penelitian studi kasus dalam penelitian ini adalah upaya mengumpulkan data dengan menggunakan berbagai sumber informasi khususnya berkaitan dengan penanaman nilai pendidikan Agama Islam di MI Al Ikhlas. Pertimbangan ini sesuai dengan pendapat John W. Creswell yang mengartikan studi kasus sebagai pendekatan kualitatif yang penelitiannya mengeksplorasi kehidupan nyata, sistem terbatas kontemporer (kasus) atau beragam sistem terbatas (berbagai kasus), melalui pengumpulan data yang detail dan mendalam yang melibatkan berbagai sumber informasi. ${ }^{10}$ Adapun dalam pengumpulan data, peneliti menggunakan teknik observasi dan wawancara. Tehnik observasi partisipan dilakukan karena peneliti ingin terlibat dalam kegiatan sehari-hari

\footnotetext{
9 Sugiyono, Metode Penelitian Kuantitatif, Kualitatif dan R\&D, (Bandung: Alfabeta, 2016), 11

${ }^{10}$ John W. Creswell, Penelitian Kualitatif \& Desain Riset, (Yogyakarta: Pustaka Pelajar, 2015), 135.
} 
subjek yang sedang diamati. ${ }^{11}$ Untuk teknik wawancara peneliti menggunakan teknik wawancara tak terstruktur. Untuk menguji keabsahan data menggunakan triangulasi sumber, triangulasi teknik dan triangulasi waktu. $^{12}$

\section{HASIL DAN PEMBAHASAN TEMUAN}

Wabah virus corona yang saat ini melanda seluruh penjuru dunia telah memaksa masyarakat untuk melakukan semua pekerjaan dari rumah dan tidak melakukan kegiatan yang berpotensi berkerumun di tempat-tempat umum dengan tujuan untuk menghentikan penyebaran virus yang ada, termasuk dalam pelaksanaan belajar mengajar di lembaga pendidikan dengan meniadakan aktivitas belajar selama 14 hari dan dialihkan menjadi sekolah berbasis jaringan atau daring. Siti Ruqoiyah mengatakan, "Saat awal mula pandemi di bulan Maret, sesuai dengan edaran menteri yang ada, kami meminta dan menghimbau kepada semua dewan guru baik guru kelas maupun guru mata pelajaran, mulai dari kelas satu hingga kelas enam untuk memberikan tugas rumah kepada anak-anak agar bisa dijadikan bahan pembelajaran mandiri selama 14 (empat belas) hari dan wajib dikumpulkan ketika pembelajaran aktif kembali." 13

Selama 14 (empat belas) hari kedepan, setelah turunnya edaran menteri pendidikan tersebut, peserta didik mengerjakan tugas yang telah diberikan oleh masing-masing guru yang mengajar di tiap-tiap kelas. Tugas tersebut harus diselesaikan dan dikumpulkan, kemudian diperiksa oleh bapak ibu guru di hari pembelajaran mulai aktif kembali. Tidak hanya Tematik dan mata pelajaran umum lainnya, bahkan materi Pendidikan Agama Islam yang meliputi Akidah, Fikih, Al-Qur'an Hadis dan Sejarah Kebudayaan Islam (SKI) harus disampaikan kepada peserta didik melalui pemberian tugas untuk dikerjakan selama 14 (empat belas) hari dan akan

\footnotetext{
${ }^{11}$ Sudarwan Danim, Menjadi Peneliti Kualitatif, (Bandung: Pustaka Setia, 2002), 140.

12 Sugiyono., 273.

${ }^{13}$ Siti Ruqoiyah, Wawancara, Srono, 2 Desember 2020.
} 
diperiksa atau dikoreksi oleh guru masing-masing saat pertemuan berikutnya.

Pelaksanaan pembelajaran ini berlangsung sampai proses Penilaian Akhir Semester (PAS). Saat pelaksanaan PAS pun tidak dilakukan di sekolah, melainkan dengan cara pengambilan naskah soal oleh wali murid dan dikerjakan di rumah masing-masing peserta didik, dan wajib dikumpulkan di rumah wali kelas sesuai jadwal ujian yang telah ditetapkan. ${ }^{14}$ Siti Ruqoiyah mengatakan "Pembelajaran semacam ini belum bisa menuntaskan materi dasar bagi peserta didik tingkat MI, dan kami yang tergabung dalam Kelompok Kerja Madrasah (KKM) saat melakukan pertemuan, menyepakati untuk mengadakan pendampingan di tahun pelajaran berikutnya untuk peserta didik dengan memperhatikan zona. Hanya zona hijaulah yang diizinkan pendampingan. Pendampingan boleh dilakukan di rumah masing-masing guru ataupun di rumah salah satu peserta didik dengan memperhatikan protokol kesehatan dan menjaga jarak dengan cara satu kali pendampingan diikuti oleh kurang dari 18 (delapan belas) peserta didik."15

Pada tanggal 13 Juli 2020, pendampingan mulai diberikan kepada peserta didik dan dilakukan dua kali dalam satu minggu untuk setiap kelasnya dan menggunakan jadwal sesi untuk peserta didik setiap kelasnya. Mulai dari kelas 1 (satu) sampai kelas 6 (enam) menjadi 12 kelas dan durasi pendampingan paling lama 1 (satu) jam atau 60 (enam puluh) menit. ${ }^{16}$ Siti Ruqoiyah juga menyampaikan "Kebijakan yang disepakati bersama KKM dan dilaksanakan di setiap satuan MI di Kecamatan Srono ini sifatnya tidak memaksa, jika ada wali murid yang memiliki tingkat kekhawatiran dengan putra-putrinya yang harus bertemu banyak orang, maka diizinkan bagi peserta didik tersebut untuk tidak mengikuti pendampingan dan

\footnotetext{
${ }^{14}$ Observasi, Seono, 8 Juni 2020.

${ }^{15}$ Siti Ruqoiyah, Wawancara, Srono, 2 Desember 2020.

${ }^{16}$ Dokumentasi pesan Whatsapp, 12 Juli 2020.
} 
mendapatkan materi pembelajaran melalui Whatsapp sebagai bentuk pembelajaran daring.,"17

Dari sudut pandang guru, pendampingan ini sangat memberikan kemudahan untuk menyampaikan materi pembelajaran serta memantau langsung apakah nilai-nilai yang diajarkan telah dapat diterima dan diproses dalam diri peserta didik dengan baik atau belum. Lilik Hariani selaku guru kelas 1 (satu) mengatakan "Untuk membimbing dan memantau kemampuan baca, tulis dan berhitung peserta didik, kebijakan pendampingan ini memang sangat perlu diberikan kepada peserta didik kelas 1 (satu). Mengingat pembelajaran full daring yang dilakukan kemarin, banyak ditemukan peserta didik kurang mampu meningkatkan kemampuan dasar ini." 18

Siti Dewi Masitah selaku salah satu guru mata pelajaran Agama Islam mengatakan: "Selama pendampingan, kami guru Agama bisa menekankan nilai-nilai Agama Islam dengan lebih maksimal lagi dibandingkan dengan saat pembelajaran daring yang hanya bisa memantau peserta didik melalui pengumpulan tugas lewat Whatsapp saja. Saat pendampingan kami lebih mudah menjelaskan tentang nilai-nilai luhur terkait pendidikan Agama Islam." ${ }^{19}$ Sayang sekali pendampingan ini tidak bisa dilakukan dalam waktu yang lama oleh guru-guru MI Al Ikhlas dikarenakan pada akhir bulan Agustus, Banyuwangi menjadi zona merah dan pembelajaran pun harus kembali lagi daring. Abd. Syukur selaku salah satu guru mata pelajaran Agama Islam mengatakan:

"Metode pembelajaran yang paling efektif dan efisien saat daring adalah pemberian tugas praktik salat dan harus dikumpulkan dengan mengirim video praktik salat ke grup kelas whatsapp. Meski kami tidak bisa memberikan kritik dan saran pembetulan gerakan secara langsung, akan tetapi video yang dikirimkan dapat menjadi bahan pembahasan saat kelas pendampingan boleh dilakukan kembali. Selain praktik salat, tugas yang

\footnotetext{
${ }^{17}$ Siti Ruqoiyah, Wawancara, Srono, 2 Desember 2020.

${ }^{18}$ Lilik Hariani, Wawancara, Srono, 4 Desember 2020.

${ }^{19}$ Siti Dewi Masitah, Wawancara, Srono, 4 Desember 2020.
} 
pernah saya berikan saat daring salah satunya adalah praktik membaca dan menghafal Al-Qur'an. Mekanismenya juga sama yaitu mengumpulkan video yang menampilkan peserta didik sedang menghafalkan ayat pendek yang kami minta. Selain itu kami juga menggunakan deskripsi sikap seseorang yang kemudian harus dipraktikkan peserta didik dalam bentuk video yang kemudian video ini harus dikirim kepada kami."20

Dalam penjelasan Abd. Syukur mengenai sistematika penugasan mengirim video praktik salat serta membaca dan menghafal Al-qur'an terdapat sebuah pola baru dalam penanaman nilai-nilai pendidikan Agama Islam, yaitu keterlibatan orang tua secara langsung. Dulu ketika pembelajaran normal, orang tua hanya tahu anak-anaknya berangkat sekolah, belajar di sekolah, dan mengerjakan tugas rumah sendiri. Ketika pembelajaran berubah menjadi daring, maka orang tua terlibat langsung dalam pembelajaran, dimana orang tua membantu putra-putrinya memahami materi pelajaran dan membantu putra-putrinya menyelesaikan tugas yang diberikan oleh guru mereka.

Selain melalui pembelajaran daring dan pendampingan luring yang sangat singkat, salah satu usaha menanamkan nilai-nilai pendidikan Agama Islam kepada peserta didik di MI Al Ikhlas selama pandemi Covid-19 adalah dengan mengadakan peringatan tahun baru hijriah bersamaan dengan santunan anak yatim piatu. Kegiatan ini diadakan dengan tujuan untuk menanamkan dan menumbuhkan rasa empati serta melatih jiwa gemar berbagi dengan teman, khususnya anak yatim piatu. Acara yang diadakan tentunya sangat sederhana dan sangat memperhatikan protokol kesehatan. Jumlah peserta yang menghadiri juga terbatas mengingat harus jaga jarak dan masih dalam kondisi pandemi. ${ }^{21}$

${ }^{20}$ Abd. Syukur, Wawancara, Srono, 4 Desember 2020.

${ }^{21}$ Dokumentasi kegiatan MI Al Ikhlas Bagorejo. 


\section{PEMBAHASAN TEMUAN}

\section{Pelaksanaan Pembelajaran di MI Al-Ikhlas Pada Masa Pandemi Covid-19}

Pelaksanaan pembelajaran peserta didik MI Al Ikhlas selama pandemi dilakukan dengan dua cara (daring dan luring). Hal ini sesuai dengan Surat Edaran dari Kementrian Pendidikan dan Kebudayaan (Mendikbud) nomor 36952/MPK.A/HK/2020, dinyatakan bahwa dalam rangka pencegahan terhadap perkembangan dan penyebaran Coronavirus Disease (Covid-19), Kementerian menghimbau untuk melakukan hal-hal sebagai berikut:

1. Menjaga pegawai, mahapeserta didik, peserta didik, guru dan dosen dengan mengikuti protokol pencegahan Covid-19 yang disampaikan di Kantor Staf Presiden.

2. Memastikan bahwa pengendalian, kewaspadaan, dan penanganan penyebaran Covid-19 di masing-masing unit kerja telah dilaksanakan dengan baik sesuai dengan Surat Edaran Menteri Pendidikan dan Kebudayaan Nomor 2 Tahun 2020 dan Nomor 3 Tahun 2020 tentang pencegahan dan penanganan Covid-19, Tanggal 9 Maret 2020.

3. Menunda penyelenggaraan acara yang mengundang banyak peserta atau menggantinya dengan video conference atau komunikasi daring lainnya.

4. Khusus daerah yang terdampak oleh Covid-19 berlaku ketentuan sebagai berikut:

a. Memberikan pembelajaran secara daring dari rumah bagi peserta didik.

b. Pegawai dan guru melakukan aktivitas bekerja, mengajar atau memberi kuliah dari rumah (Bekerja Dari Rumah/ BDR) melalui video conference, digital documents, dan sarana daring lainnya. Sebagai informasi, berbagai lembaga penyedia sarana pembelajaran daring secara gratis sebagaimana tercantum dalam lampiran yang merupakan bagian tidak terpisahkan dari Surat Edaran ini. 
c. Pelaksanaan BDR tidak mempengaruhi tingkat kehadiran (dipandang sama seperti bekerja di kantor, sekolah atau perguruan tinggi, tidak mengurangi kinerja dan tidak mempengaruhi tunjangan kerja).

d. Apabila harus datang ke kantor/ kampus/ sekolah sebaiknya tidak menggunakan sarana kendaraan umum yang bersifat massal.

5. Pimpinan Satuan Kerja melakukan kerja sama dengan dinas kesehatan setempat untuk melakukan pemeriksaan kesehatan apabila ada pegawai/ mahapeserta didik/ peserta didik yang mengalami sesak nafas, demam, dan batuk.

6. Pimpinan Satuan Kerja membuat pedoman pelaksanaan BDR dan pembelajaran daring disesuaikan dengan kebutuhan setempat. ${ }^{22}$

\section{Penanaman Nilai-nilai Pendidikan Agama Islam di MI Al Ikhlas Srono}

Dalam pelaksanaannya yang sudah disebutkan dalam pembahasan temuan, nilai-nilai Agama Islam yang ditanamkan kepada peserta didik MI Al Ikhlas meliputi nilai keimanan, nilai ibadah, nilai akhlak.

\section{Nilai Keimanan}

Iman secara umum dapat dipahami sebagai suatu keyakinan yang dibenarkan dalam hati, diikrarkan dengan lisan, dan dibuktikan dengan amal perbuatan yang didasari niat yang tulus, ikhlas dan selalu mengikuti petunjuk Allah SWT serta sunah Nabi Muhammad SWT. ${ }^{23}$ Nilai keimanan ini ditanamkan secara langsung oleh guru MI Al Ikhlas dan juga secara daring, sebagai contoh melalui pembelajaran Sejarah Kebudayaan Islam (SKI) peserta didik dapat mengetahui perjuangan umat Islam dalam menegakkan agama Allah, sehingga dengan ini peserta didik dapat menambah keyakinan hatinya terhadap Agama Islam.

\footnotetext{
${ }^{22}$ Mendikbud, Pembelajaran Secara Daring dan Bekerja dari Rumah untuk Mencegah Penyebaran Covid-19, https://www.kemdikbud.go.id/main/blog/2020/03/se-mendikbudpembelajaran-secara-daring-dan-bekerja-dari-rumah-untuk-mencegah-penyebaran-covid19, diakses pada 1 Oktober 2020.

${ }^{23}$ Nur Hudah, "Penanaman Nilai-Nilai Islam dalam Membentuk Akhlak Mulia Melalui Kegiatan Mendongeng di TK Terpadu Nurul Amal Buyuk Bringkang Menganti Gresik”, Fikroh: Jurnal Pemikiran dan Pendidikan Islam, Vol. 12, No. 2 (Juli 2019), 5-6.
} 


\section{Nilai Ibadah}

Ibadah secara bahasa berarti merendahkan diri serta tunduk. Sedangkan menurut syara' ibadah mempunyai banyak definisi, tetapi makna dan maksudnya satu. Di antaranya yaitu: a) Ibadah adalah taat kepada Allah SWT. b) Ibadah adalah merendahkan diri pada Allah SWT. c) Ibadah adalah sebutan yang mencakupi seluruh apa yang dicintai dan di ridhai Allah SWT. Namun, secara garis besar ibadah dalam Islam terbagi menjadi dua yakni mahdah (khusus) seperti salat, puasa, haji dan lain-lain. Kemudian ghoiru mahdah (umum) seperti sedekah, membaca Al-Qur'an dan lain sebagainya. ${ }^{24}$ Dalam menanamkan nilai-nilai ibadah, para guru melakukan kerja sama dengan orang tua untuk terus memantau ibadah anak dan juga dengan tugas-tugas yang diberikan akan membantu orang tua memudahkan mengontrol proses pembelajaran daring tersebut dibarengi dengan penjelasan guru yang dijelaskan melalui grup kelas di aplikasi whatsapp.

Nilai Akhlak

Imam Al-Ghazali dalam Abdurrahman mengatakan, bahwa akhlak adalah sifat yang tertanam dalam jiwa yang dapat menimbulkan perbuatanperbuatan dengan mudah tanpa melalui pemikiran dan pertimbangan. ${ }^{25}$ Untuk memantapkan nilai-nilai akhlak, para guru MI mengajak peserta didik terjun langsung melalui kegiatan-kegiatan salah satunya adalah kegiatan santunan anak yatim piatu.

\section{Metode Penanaman Nilai-Nilai Agama di MI Al Ikhlas Srono}

\section{Metode Praktik}

Metode praktik yang dilakukan sedikit berbeda, dalam hal ini peserta didik membuat video atas dirinya sendiri atau dibantu orang tua dan kemudian video tersebut dikirimkan kepada guru untuk dievaluasi. AlJamali dalam Eko Saputro menjelaskan metode praktik untuk belajar dengan

\footnotetext{
${ }^{24}$ Nur Hudah, "Penanaman Nilai-nilai Islam ...", 5-6.

25 Abdurrahman, "Meningkatkan Nilai-nilai Agama pada Anak Usia Dini Melalui Pembinaan Akhlak”, Jurnal Penelitian Keislaman, Vol.14, No. 1 (2018). 67-68.
} 
praktik adalah salah satu di antara metode mutakhir yang diserukan oleh pendidikan modern. ${ }^{26}$ Maka pendidikan Islam bukan diberikan secara teori saja, akan tetapi dilakukan pula dengan cara praktik. Pembentukan akhlak dan rohani seseorang tidaklah cukup dengan sekadar nasehat, tetapi memerlukan praktik nyata, sehingga akhlak mulia dapat terbentuk dalam pribadinya dan hubungan yang harmonis sesama manusia dapat terjalin dengan baik.

Tahapan dalam metode ini yang dilakukan oleh guru MI Al Ikhlas selama pandemi adalah:

a. Guru mengirimkan prosedur penugasan melalui grup kelas Whatsapp kemudian meminta peserta didik mengumpulkan video praktik yang dibantu oleh orang tua dalam proses pembuatannya.

b. Peserta didik mengerjakan tugas yang diberikan dengan mengikuti prosedur yang telah diberikan oleh guru.

c. Peserta didik mengirimkan video berisikan tugas praktik ke nomor Whatsapp guru yang bersangkutan (untuk memudahkan penilaian).

d. Guru memberikan feedback berupa kritik dan saran dari video yang telah dikirimkan.

\section{Metode Bimbingan}

Membimbing dalam artian mengarahkan peserta didik untuk terus melakukan kegiatan-kegiatan yang berkaitan dengan nilai-nilai Agama Islam sehingga hal tersebut menjadi sebuah kebiasaan yang terbangun dalam alam bawah sadar mereka. menurut Miller dalam Eko Saputro, bimbingan adalah proses bantuan terhadap individu untuk mencapai penanaman diri dan pengarahan diri yang dibutuhkan untuk melakukan penyesuaian diri secara maksimum kepada sekolah, keluarga, serta masyarakat. $^{27}$

\footnotetext{
${ }^{26}$ Eko Saputro. “Penanaman Nilai-Nilai Agama Islam Melalui Kegiatan Cinta Alam”, Mudarrisa: Jurnal Kajian Pendidikan Islam, Vol. 7, No. 1 (Juni 2015), 129.

${ }^{27}$ Eko Saputro, “Penanaman Nilai-Nilai Pendidikan Agama Islam...", 130.
} 
Tahapan dalam metode ini, yang dilakukan oleh guru MI Al Ikhlas selama pandemi adalah:

a. Peserta didik datang ke sekolah dengan mematuhi protokol kesehatan sesuai dengan SOP Covid-19.

b. Peserta didik masuk ke dalam kelas dengan posisi tempat duduk yang berjarak satu meter untuk setiap peserta didiknya.

c. Bimbingan dilakukan saat pendampingan dalam kurun waktu maksimal 60 (enam puluh) menit. Guru memberikan arahan dari setiap tugas yang telah dikirimkan lewat Whatsapp.

d. Memberikan materi baru yang berkaitan dengan materi pembelajaran Pendidikan Agama Islam yang membutuhkan bimbingan lebih.

\section{Metode Hafalan}

Metode hafalan ini digunakan untuk menunjang pembelajaran peserta didik dalam menanamkan nilai-nilai Agama Islam melalui hafalan ayat-ayat Al-Qur'an atau hadis beserta artinya akan secara tidak sadar membiasakan peserta didik untuk membaca berulang-ulang kemudian bisa menjadi pedoman bagi mereka tentunya dengan kelanjutan arahan dari guru. Yusuf Tayar dalam Devi Suci menjelaskan bahwa metode hafalan adalah cara menyajikan materi pelajaran dengan meminta peserta didik untuk menghafal kalimat-kalimat berupa ayat-ayat Al-Qur'an, hadis, syair, cerita, kata-kata hikmah, dan lain-lain yang menarik hati. ${ }^{28}$

Tahapan dalam metode ini yang dilakukan oleh guru MI Al Ikhlas selama masa pandemi adalah:

a. Guru menyampaikan surah pendek mana saja yang harus dihafalkan melalui grup kelas whatsapp.

b. Guru memberikan arahan agar orang tua membantu peserta didik dalam proses menghafal dan kemudian membantu peserta didik untuk merekam video hafalan.

${ }^{28}$ Devi Suci Windariyah, "Kebertahanan Metode Hafalan dalam Pembelajaran Bahasa Arab”, Ta'lim: Jurnal Studi Pendidikan Islam, Vol. 1, No. 2 (Juli 2018), 98. 
c. Guru menyampaikan agar mengirim video hafalannya dikirim langsung kepada guru melalui nomor Whatsapp pribadi milik guru pengampu mapel.

d. Guru juga menyampaikan bagi peserta didik yang belum mengirimkan videonya dapat langsung menghadap saat pendampingan pembelajaran dengan mematuhi protokol kesehatan sesuai SOP Covid-19.

\section{SIMPULAN}

Pelaksanaan pembelajaran bagi peserta didik dalam situasi pandemi dilakukan dengan dua cara, yakni secara daring dan luring dengan tetap memperhatikan protokol kesehatan dan arahan dari pusat. Kedua cara tersebut dilakukan ketika kondisi kabupaten masih dalam zona hijau dari wabah Covid-19 dan ketika sudah dinyatakan zona merah, maka pembelajaran dilakukan secara daring. Nilai-nilai yang ditanamkan kepada peserta didik meliputi nilai ibadah, nilai keimanan, dan nilai akhlak. Sedangkan metode-metode yang digunakan oleh guru dalam proses penanaman nilai-nilai Agama Islam selama pandemi adalah metode praktik, metode bimbingan dan metode hafalan.

\section{DAFTAR PUSTAKA}

Abdurrahman. "Meningkatkan Nilai-Nilai Agama pada Anak Usia Dini Melalui Pembinaan Akhlak", Jurnal Penelitian Keislaman, Vol. 14, No. 1, 2018.

Aji, Rizqan Halal Syah. "Dampak Covid-19 Pada Pendidikan Di Indonesia: Sekolah, Keterampilan, dan Proses Pembelajaran”, Salam: Jurnal Sosial \& Budaya Syar'i FSH UIN Syarif Hidayatullah Jakarta Vol. 7, No. 5, 2020.

Creswell, John W. Penelitian Kualitatif \& Desain Riset, Yogyakarta: Pustaka Pelajar, 2015.

CNN Indonesia, "Dampak Resesi Corona Mengalir ke Berbagai Sektor" dalam https://cnnindonesia.com/ekonomi/20200908105412-532543899/dampak-resesi-corona-mengalir-ke-berbagai-sektor/, diakses pada 09 September 2020. 
Danim, Sudarwan. Menjadi Peneliti Kualitatif, Bandung: Pustaka Setia, 2020.

Depdiknas. "Undang-undang Sistem Pendidikan Nasional No. 20 Tahun 2003”, Jakarta: Sinar Grafika, 2014.

Hudah, Nur. "Penanaman Nilai-Nilai Islam dalam Membentuk Akhlak Mulia Melalui Kegiatan Mendongeng di TK Terpadu Nurul Amal Buyuk Bringkang Menganti Gresik”, Fikroh: Jurnal Pemikiran Dan Pendidikan Islam, Vol. 12, No.2, Juli 2019.

Mendikbud, Kamus Besar Bahasa Indonesia, https://kbbi.kemdikbud.go.id/entri/daring, diakses pada 15 Oktober 2020.

Mendikbud, Pembelajaran Secara Daring dan Bekerja dari Rumah untuk Mencegah Penyebaran Covid-19, https://www.kemdikbud.go.id/main/blog/2020/03/se-mendikbudpembelajaran-secara-daring-dan-bekerja-dari-rumah-untukmencegah-penyebaran-covid19, diakses pada 1 Oktober 2020.

Saputro, Eko. "Penanaman Nilai-Nilai Agama Islam Melalui Kegiatan Cinta Alam”, Mudarrisa: Jurnal Kajian Pendidikan Islam, Vol. 7, No. 1, Juni 2015.

Sugiyono. Metode Penelitian Kuantitatif, Kualitatif dan $R \& D$. (Bandung: Alfabeta, 2016).

UNESCO, Education Transforms Lives, https://en.unesco.org/themes/education, diakses pada09 September 2020.

Windariyah, Devi Suci. "Kebertahanan Metode Hafalan dalam Pembelajaran Bahasa Arab”, Ta'lim: Jurnal Studi Pendidikan Islam, Vol. 1, No. 2, Juli 2018.

WHO, "Corona Virus Disease (Covid-19)" dalam https://www.who.int/emergencies/diseases/novel-coronavirus2019/question-and-answers-hub/q-a-detail/coronavirus-diseasecovid-19, diakses pada 08 September 2020. 